UDC 342.726-055.2(549.1)

CERIF: S112, S114, S130, H250, H300

DOI: 10.51204/HLH_20110A

\author{
HASSAN Amna*
}

\title{
WOMEN IN PAKISTAN - A COMPARATIVE ANALYSIS OF WOMEN'S RIGHTS ON THE BASIS OF ANGLO-SAXON AND MUSLIM LEGAL TRADITIONS
}

This paper draws attention towards the legal status of women in the Anglo-Saxon (common law) and Muslim legal traditions (Sharia law) of the Islamic Republic of Pakistan. In the beginning, the paper provides elaboration on the concept and historical background of Sharia law. The paper then chalks out in detail the historical background of women's status in Pakistan based on two basic parameters, that is, on the basis of their rights under Sharia law and on the basis of their rights under common law i.e. the Constitution and legal Statutes. Although Sharia law generally treats women as equal to men, there are still certain matters in which women are treated unequally such as marriage, divorce, inheritance, property rights, etc. The paper then concludes with a comprehensive analysis of the rights of women in Pakistan under both systems of law through a study of case-law.

Keywords: Women in Pakistan. - Status and Rights. - Sharia Law. - Common Law. - Case-Study.

\section{INTRODUCTION}

Pakistan bears a mixed legal system, that is, a combination of Sharia law and common law. The Sharia law (also known as Islamic law) has been in existence along with other cultural norms during the early

* Doctoral student at the University of Pecs Faculty of Law,

hassan.amna@ajk.pte.hu, maryshah28@gmail.com

This paper is part of my doctoral thesis project titled, 'Comparative Analysis of Core Issues of Contract Law regarding Anglo-Saxon, Continental, and Sharia Legal Systems with respect to the relevant Statuses of Women'. It forms part of chapter 3 of the thesis. It has also been accepted for the Iustoria 2020 conference, which has been postponed due to the coronavirus pandemic. 
Islamic states of the $18^{\text {th }}$ and $19^{\text {th }}$ century. ${ }^{1}$ By definition, Sharia law is a fundamental religious law that forms the core of Islamic tradition. According to the long-standing theory of Islamic Jurisprudence, there are four fundamental sources of Sharia law, namely the Holy Quran, Sunnah (acts and sayings of the Prophet), Ijma (juridical consensus) and Qiyas (analogical reasoning). ${ }^{2}$ Several schools of thought in Islam, (including Hanafi, Maliki, Shafi'i, Hanbali and Jafari) developed their legal methodologies in accordance with the teachings of these four basic sources of Islamic law. ${ }^{3}$ The traditional jurisprudence, referred to as fiqh under Sharia law, makes a distinction between two fundamental branches of Sharia law into ibadat (rituals) and muamalat (social relations). This distinction gives rise to a variety of topics, ${ }^{4}$ which leads to an overlapping of certain Sharia law notions with that of the Western law, whereas certain Sharia Law issues remain intact, emphasizing the need to live in accordance with the teachings of Islam.

Traditionally, Sharia law was construed by independent muftis (commonly referred to as jurists), based on the teachings of Islam and various legal sources. The figh was expounded through the help of religious scholars, mostly by way of legal opinions (also known as fatwas) issued by expert jurists. Historically, figh was enforced in the Sharia courts by a judge, who was appointed by the ruler of that time. It was the duty of the judge to settle issues relating to civil disputes and societal matters, while criminal justice was ensured and administered by the Sultanic courts, police, and market inspectors, who were given the discretion to decide such matters either in accordance with the Sharia law or State law. ${ }^{5}$ The minority communities (usually non-Muslims) enjoyed legal independence in matters pertaining to personal status, where Sharia law was no longer applied and they were given autonomy to seek justice in the light of their own religion.

Nevertheless, at present, several Statutes based on European models are in regulation in most of the Muslim countries attempting to replace

1 Jan Michiel Otto, Sharia Incorporated: A Comparative Overview of the Legal Systems of Twelve Muslim Countries in Past and Present, Leiden University Press, Leiden 2009, 615-616.

2 John L. Esposito, Natana J. DeLong-Bas, Women in Muslim family law, Syracuse University Press, US 2001, 2.

3 John L. Esposito, Islamic Law: The Oxford Dictionary of Islam, Oxford University Press, Oxford 2014.

4 Norman Calder, "Law: Legal Thought and Jurisprudence", John L. Esposito (ed.), The Oxford Encyclopedia of the Islamic World, Oxford University Press, Oxford 2009.

5 Farhat J. Ziadeh, "Criminal Law", John L. Esposito (ed.), The Oxford Encyclopedia of the Islamic World, Oxford University Press, Oxford 2009. 
the classical Sharia laws. ${ }^{6}$ Not only this, the Muslim countries also brought their legal education and judicial practices in accordance with the European practice. Although most of those Muslim countries still hold on to the notions of Sharia law in their constitutions, those classical notions of Sharia law have been restricted to family laws or personal status laws. The Legislative bodies in those Muslim countries aimed at codifying the rules of Sharia in an attempt to modernize them to match the changing needs of the times, without abandoning their basis in traditional jurisprudence. ${ }^{7}$ In the $20^{\text {th }}$ century, Islamist movements called for the complete implementation and enforcement of Sharia law, together with hudud punishments e.g. stoning to death. In certain cases, this Islamization led to classical legal reform, whilst in other cases some progressive reformers advocated for the reinterpretation of Sharia by the qualified judiciary. ${ }^{8}$ Although these hudud punishments are granted exaggerated importance in international media, the Muslim countries are reluctant in enforcing such punishments in their territories and their implementation is based in accordance with the political climate of the country. ${ }^{9}$

There are several instances where non-Muslim countries allow for the use of Sharia law for their Muslim-minority in matters of personal status. ${ }^{10}$ On the other hand, there are some non-Muslim countries where a significant Muslim minority has made several calls for adoption of Sharia law in the legal system and these calls have become hotly debated on an international level. ${ }^{11}$ In addition, several Islamic movements in Muslim-majority countries like Pakistan have called for reinstating Sharia law in the legal system referring to their demand as 'a longstanding goal for Islamist movements, ${ }^{12}$ and such calls for reinstating or ex-

6 Jan Michiel Otto, Sharia and National Law in Muslim Countries: Tensions and Opportunities for Dutch and EU Foreign Policy, Amsterdam University Press, Netherland 2008, 19.

$7 \quad$ Ibid.

8 Intisar A. Rabb, "Law: Civil Law \& Courts", John L. Esposito (ed.), The Oxford Encyclopedia of the Islamic World, Oxford University Press, Oxford 2009.

9 Ibid., 20.

10 Tad Stahnke, Robert C. Blitt, "The Religion-State Relationship and the Right to Freedom of Religion or Belief: A Comparative Textual Analysis of the Constitutions of Predominantly Muslim Countries", Georgetown Journal of International Law 36/2005, 13-19.

11 Tom Brooks-Pollock, "The countries where a majority of Muslims want to live under Sharia law", The Independent, https://www.independent.co.uk/news/world/countries-where-majority-muslims-want-live-under-sharia-law-a6773666.html, last visited 20.4.2020.

12 Ira Lapidus, The Cambridge Illustrated History of the Islamic World, Cambridge University Press, Cambridge 1996, 293-98. 
panding Sharia law are accompanied with controversy, ${ }^{13}$ violence, ${ }^{14}$ and even warfare.

When Pakistan gained independence in 1947, English laws remained in force until a new constitution was chalked out. The founder and father of Pakistan - Muhammad Ali Jinnah - envisaged a legal system for Pakistan in complete compliance or consonance with the teachings of Islam, which could not become a reality in his lifetime. Nevertheless, Jinnah was successful in formulating the political ideology of the country. During his law studies at Lincoln's Inn, Jinnah found British liberalism attractive and appealing. This ideal of British liberalism appealed to him so much so that he incorporated the English common law into the Pakistani legal system upon its independence. ${ }^{15} \mathrm{He}$ assumed for himself the role of a ceremonial figurehead of Pakistani politics and therefore, Pakistan became a common law system country, with an adversarial court procedure and other common law practices, such as the judicial precedent and the idea of stare decisis. ${ }^{16}$

However, there are considerable differences between the Pakistani common law system and the traditional one. Firstly, the laws in Pakistan are entirely codified, be they civil or criminal laws. This is due to the enactment of Statutes by the British during their rule in the subcontinent. ${ }^{17}$ Secondly, the ideal of jury trials no longer exists in Pakistani common law due to dissatisfaction with its operation and mistrust from both the judiciary and the public. One Pakistani judge was reported calling these jury trials 'amateur justice. ${ }^{18}$ Thirdly, Pakistani jurisprudence is by-and-large influenced by the US-style Federal Structure with regards to its constitution. ${ }^{19}$ Fourthly, Sharia law, along with the traditional jirga system, bears an influence on the judicial development of the country. ${ }^{20}$

13 Masako IIjima, "Islamic Police Tighten Grip on Indonesia's Aceh", Reuters, https:// www.reuters.com/article/us-indonesia-aceh-police-idUSTRE60D07420100114, last visited 20.4.2020.

14 Roza Ibrahimova, "Dozens Killed in Violence in Northern Nigeria", Al Jazeera, https://www.dailymotion.com/video/xr5wnq, last visited 20.4.2020.

15 Asghar Ali Engineer, They Too Fought for India's Freedom: The Role of Minorities, Hope India Publications, Gurgaon 2006, 72.

16 Shaun D Pattinson, "The Human Rights Act and the doctrine of precedent", Legal Studies 35/2015, 142-164.

17 Amna Hassan, "Impact of the European Private Law Codification Outside Europe I: Common Law in the Old Colonial Empire", Dezső Márkus Research Group for Comparative Legal History (DIKE), 3/2020, 172.

18 Feisal Naqvi, "Dispute Resolution: A Jury of One", The Counsel, Pakistan 3/2013.

19 Kashif Mahmood Tariq, "Impact of Anglo-American Jurisprudence on The Pakistan's Legal system”, Pakistan Journal of Islamic Research, Pakistan 17/2016, 127.

20 Azam Chaudhary, “The Rule of Law Problems in Pakistan: An Anthropological Perspective of the Daughter's Traditional Share in the Patrimony in the Punjab", Pakistan Journal of History and Culture, 30/2009, 101-103. 
Keeping in view Jinnah's vision of an Islamic state, ${ }^{21}$ the ulama or Islamic clergy became closely associated with Jinnah and acquired strength. After Jinnah's demise (just one year after gaining independence), one of the ulama - namely, Maulana Shabbir Ahmad Usmani - portrayed Jinnah as the greatest Muslim after the Mughal Emperor Aurangzeb and also compared his death to the demise of the Prophet.

Jinnah's view of converging the two differing legal systems, which is common law and Sharia law, was long carried on by the leaders of $\mathrm{Pa}$ kistan and it had a lasting impact on the lawmakers in Pakistan in later times. The initial steps to transform the country into the desired Islamic state, as postulated by Jinnah, were taken by the very first Prime Minister of Pakistan - Liaquat Ali Khan. He presented the Objectives Resolution before the Constituent Assembly in 1949,22 which clearly gave the entire sovereignty in the universe to the God. ${ }^{23}$ Not only this, the then president of the leading political party (Muslim League) in Pakistan shared his intentions of bringing together all the Muslim nations in the world into one entity, i.e. a pan-Islamic entity. ${ }^{24}$ However, this pan-Islamic approach was not received in the same context by other Muslim nations at that time, simply due to the origin and basis of development of such nations. In many Muslim nations, the ideals of nationalism were built not only on Islam but also on other essential factors like ethnicity, language and culture.

As Pakistan was from the beginning separated into two wings - the East and West Pakistan - the East Pakistanis were suffering enormously at the hands of the minority West Pakistan wing. Therefore, in 1971, the East wing finally achieved independence from the West wing and became a new country (now known as Bangladesh). As a result of the elections already held in 1971, the Pakistan People's Party (PPP) won the elections and became the first elected government of West Pakistan (now known as the Islamic Republic of Pakistan) in years from 1947. This party was successful in constituting a legislative body capable of bringing a landmark constitution in the country in $1973,{ }^{25}$ known as the Constitution of 1973. Under this Constitution, the country was declared to be an Islamic Republic, i.e. Islam became the state religion. It also declared that the entire laws in force in the country should be brought in accordance with

21 Nadeem F. Paracha, “The first Pakistani?", DAWN, https://www.dawn.com/ news/1175127, last visited 20.4.2020.

22 Rubina Saigol, "What is the most blatant lie taught through Pakistan textbooks?", Herald, DAWN, https://www.dawn.com/news/1125484, last visited 20.4.2020.

23 Shazia Rafi, "A case for Gandhara", DAWN, Pakistan, https://www.dawn.com/ news/1164469, last visited 20.4.2020.

24 Ira Marvin Lapidus, A History of Islamic Societies, Cambridge University Press, Cambridge 2002, 382-384.

25 Husssain Haqqani, Pakistan: Between Mosque and Military, Carnegie Endowment, 2010, 18. 
the teachings of Islam as enshrined in the Holy Quran and Sunnah of the Prophet. It further stated that no law in derogation of the Islamic teachings is to be enforced in the country. ${ }^{26}$ For that purpose, several institutions were established in the country, for instance the Sharia Court and Council of Islamic Ideology (CII). ${ }^{27}$

On July $5^{\text {th }}, 1977$, the government of PPP was overthrown by a military coup led by the then Army General Zia-ul-Haq. ${ }^{28}$ The centerpiece ${ }^{29}$ of his governmental policy ${ }^{30}$ was Islam and Islamization. Until Zia came into power, the Islamic revivalists had no real force in the country. But upon his arrival, they changed the entire foundation of Pakistan's legal history. Zia played a pivotal role in the move towards Islamization, possibly due to his personal piety ${ }^{31}$ and desire to acquire a political stronghold. ${ }^{32}$ He committed himself to establishing Pakistan as an Islamic state by enforcing the Sharia law. He established a parallel court system by forming the basis of Sharia courts and separate court benches ${ }^{33}$ to decide legal cases by employing Islamic doctrines. ${ }^{34} \mathrm{He}$ also added several new criminal punishments and offences to the existing Criminal law of the country, including the offences of adultery, fornication, and blasphemy, to be punished by whipping, amputation, or stoning to death, etc.

\section{STATUS OF WOMEN IN PAKISTAN}

The level of gender subordination of women in Pakistan varies based on their class and region. The simple reason behind this is the uneven development in the socio-economic sectors and the impact of tribal and feudal systems on their lives. ${ }^{35}$ Several religious groups and ulama who ac-

26 Ibid., 491.

27 Ibid., 19.

28 Sher Ali Khan, "Global connections: The crackdown on Hizbut Tahrir intensifies", Herald, DAWN, http://herald.dawn.com/news/1153325, last visited 20.4.2020.

29 Rainer Grote, Constitutionalism in Islamic Countries: Between Upheaval and Continuity. Oxford University Press, Oxford 2012, 196.

30 Khurshid Iqbal, The Right to Development in International Law: The Case of Pakistan, Routledge, 2009,198.

31 Ian Talbot, Pakistan, a Modern History, St. Martin's Press, New York 1998, 251.

32 Roger D.Long / Gurharpal Singh / Yunas Samad / Ian Talbot, State and Nation-Building in Pakistan: Beyond Islam and Security, Routledge, 2015, 167.

33 Gilles Kepel, Jihad: The Trail of Political Islam, I.B.Tauris, London 2002, 100-101.

34 Siam Heng-Heng Michael / Chin Liew Ten, State and Secularism: Perspectives from Asia, World Scientific, Singapore 2010, 360.

35 Imran Sharif Chaudhry, "Gender Inequality in Education and Economic Growth: Case Study of Pakistan”, Pakistan Horizon 60/2007, 81-91. 
quired political power during and after the reign of Zia-ul-Haq advance and support the subordination of women in Pakistan. Initially, for example, rape victims were not allowed to use DNA evidence in their cases to prove rape against the guilty party in Pakistan. However, with the passage of time, the situation in Pakistan has improved with regards to issues like these. Now the women are allowed to prove their rape through DNA evidence, which is considered and admitted as conclusive proof in Pakistani courts too. As DNA test provides the courts with adequate means of identifying the accused / perpetrators with an increased degree of expertise, the DNA technology helps the courts in reaching a better conclusion whereby the real culprit can be convicted. Therefore, the Supreme Court of Pakistan in the Salman Akram Raja vs. Government of Punjab ${ }^{36}$ case enunciated new guidelines for the concerned authorities to compulsorily administer DNA tests and preserve DNA evidence in all rape cases in Pakistan.

Moreover, there are several examples of women who held esteemed and high positions in the government of Pakistan; leading among them is the twice elected Prime-Minister Benazir Bhutto. ${ }^{37}$ Additionally, the All Pakistan Ulama Council has recently released fatwas that condemn honor killings. ${ }^{38}$ Some other improvements also surface as women traffic wardens are employed in road traffic control measures and an attempt is being made to increase the percentage of women in the police force as well. ${ }^{39}$ Despite these improvements, widespread domestic abuse, increased child marriages and rapes still remain a bitter truth of the Pakistani society.

\subsection{Historical Background of the Status of Women in Pakistan}

Historically speaking, Muslim reformers like Syed Ahmad Khan advocated for women's right to education, prohibition of polygamy, and women empowerment by way of education. Jinnah was also known to possess a positive outlook towards women's rights. His sister Fatimah Jinnah became a well-known feminist struggling to alleviate socio-economic discriminations against women and after independence she became a valiant fighter for women rights. She also organized and established several

36 Salman Akram Raja vs. Government of Punjab, Constitution Petition No. 38, $2^{\text {nd }}$ October, 2012, 2013 SCMR 203.

37 Imtiaz Tyab, "Pakistani police seeks to recruit more women", Al Jazeera, https://www. aljazeera.com/news/2014/1/7/pakistani-police-seeks-to-recruit-more-women, last visited 20.4.2020.

38 National Assembly of Pakistan, The Constitution of the Islamic Republic of Pakistan, Islamabad 2010.

39 Karen O'Connor, Gender and Women's Leadership: A Reference Handbook, SAGE Publication, London 2010, 382. 
women's groups and feminist organizations to further her mission of empowering women in the nascent country of Pakistan.

According to Jinnah's own reflections, it is clear that the majority of Muslim women supported the Pakistan movement in the 1940's and this movement was a success partly due to the un-yielding support of Muslim women from every corner, whether they were wives, mothers, daughters, etc. ${ }^{40}$ As soon as Pakistan came into being, the Muslim women were given the right to vote in 1947 and this right to vote was later confirmed during the national elections held in 1956 under the Constitution. Every constitution (1956, 1962 and 1973) in Pakistan contains an explicit provision reserving a number of seats in the Parliament for women, giving them the opportunity to participate in political processes of the country.

In 1973, the PPP government enacted a new Constitution, which is still in force in the country. This Constitution adopted the policy of gender equality in particular stating that there shall be no discrimination on the basis of sex alone'. It also provides additional protection in matters of marriage, family, mother and child along with a guarantee of 'full participation of women in all spheres of national life. ${ }^{41}$ The tenure of the PPP government (1970-1977) is considered to be a period of liberal approach towards women and their rights. Women were allowed to work for any or all government services including the civil services, which was formerly barred to them. The PPP government also ensured a seat reservation of about $10 \%$ in the National Assembly and 5\% in the provincial assemblies, without putting any further limitation on contesting general seats. ${ }^{42}$ However, the government faced an economic crisis due to the separation of East Pakistan in 1971 and therefore could not achieve much success with the implementation of all such policies regarding women's participation in legislative bodies. ${ }^{43}$ Also, several judges upheld the implementation of Sharia laws, which were often misinterpreted and went against the express provisions of the Constitution calling for non-discrimination based on sex alone. It was done based on the evidentiary requirements laid down in Zina Ordinance, which are quite strict. For instance, a woman accusing a man of rape must prove without a reasonable doubt that the man had raped her. Because of the apparent bias within the judiciary and society at

40 Dr. Mahmooda Hashmi, "Qauid-e-Azam Mohammad Ali Jinnah and the Female Leadership”, Pakistan Journal of History \& Culture 22/2001, 158-159.

41 National Assembly, The Constitution of the Islamic Republic of Pakistan, Pakistan, 12.4.1973: Art. 25; 27; 32; 34; 35.

42 Mariam S. Pal, Women in Pakistan: Country Briefing Paper, Asian Development Bank, 2000, 21.

43 I. Talbot, 202-224. 
large, many women fail to even report the rape. If a victim cannot prove to the judiciary that she has been raped, she is liable to end up in prison for adultery or non-marital intercourse. ${ }^{44}$ In the Safiabibi case, ${ }^{45}$ the twenty-year old unmarried girl was sentenced by the court to 3 years of imprisonment, 15 stripes and a fine of Rs. 1000 for the lack of sufficient evidence in establishing her rape by Maqsood.

The tenure of Zia's government is full of contradictions with regard to the status of women rights in Pakistan. On the brighter side, it is said that his regime took several steps to advance women's rights by establishing a Women's Division, a Commission on the Status of Women and a chapter on women in the Sixth Plan Development (1977-1986) for the very first time. Syeda Abida Hussain was made the chairperson for preparing this chapter, heading a group of twenty-eight professional women. The main aim envisioned in this Plan was to adopt an integrated approach to improve women's status. ${ }^{36}$ His government also doubled the quota for women's reserved seats in 1985, and appointed twenty women as members of the Majlis-e-Shoora (Federal Advisory Council). ${ }^{47}$

However, the darker side, which is a bitter truth, states that his Islamization process introduced discriminatory laws against women, including the Hudud Ordinances and Qanun-e-Shahadat Order (Law of Evidence). ${ }^{48}$ He prohibited women participation in sports and promulgated purdah. He also suspended the fundamental rights provided expressly in the 1973 Constitution, including the right to non-discrimination on the basis of sex. In reaction to Zia's controversial Hudud Ordinance, a feminist struggle arose in the 1980's, becoming the first real wave of fighting for women's rights. This feminist struggle gave rise to women associations like the Women's Action Forum (WAF) and these forums condemned the unjust laws contained in the Hudud Ordinance, raising awareness among the women in Pakistan. As these forums encompassed women from all spheres, they raised their voices against the government in the media, through protests on the streets, through educational campaigns in schools/colleges, and formulated the famous slogan - 'Men, money, mullahs and military'. ${ }^{49}$

44 Alice Bettencourt, Violence against Women in Pakistan, Litigation Report, Human Rights Advocacy Clinic 2000, 8.

45 Charles H. Kennedy, "Islamic Legal Reform and the Status of Women in Pakistan." Journal of Islamic Studies 2/1991, 48.

46 I. Tyab, 2014.

47 I. Talbot, 213-224.

48 Abdul Ghafur Muslim, "Islamization of Laws in Pakistan: Problems And Prospects", Islamic Studies 26/1987, 265-276.

49 Afiya Shehrbano Zia, "The reinvention of feminism in Pakistan", Feminist Review, 91/2009, 29-46. 
Naturally, this feminist movement gained most attraction and appeal during the rule of the female Prime Minister Benazir Bhutto, who served twice as the Prime Minister of Pakistan (1988-1990 and 1993-1996). During her tenure, the NGOs and other focus groups were granted considerable power to urge the government to make amends with regards to the status and rights of women. However, many women in Pakistan still have to undergo social, religious, economic and political hurdles, which prevent them from exercising their political rights as voters, candidates and election administrators..$^{50}$ With the turmoil in Afghanistan in the early 2000s, the Taliban took refuge within the territory of Pakistan. These Talibans implemented strict Sharia codes within the territories they acquired control upon, thus denying women their due rights and freedom guaranteed under the Constitution of Pakistan.

To add to this dismal situation, the Prime Minister Nawaz Sharif who took office in 1997 came into power by gaining strong support from Islamic parties and Mullahs. Consequently, women found themselves caught in a losing battle against the conservative and religious political rivals. ${ }^{51}$ During his time in the government, Nawaz Sharif continued the Islamization process in Pakistan, following in the footsteps of Zia-ul-Haq. He introduced Islamic laws such as the Sharia Ordinance and Bait-ul-Maal (to support needy children, widows, etc.) to push the model of an Islamic welfare state on the country. In addition, he gave the Ministry of Religion tasks in preparing reports and suggestions on measures toward Islamization. He also expanded membership of the Organization for Economic Cooperation (ECO) to all Central Asian Muslim countries, uniting them into a Muslim Bloc. ${ }^{52}$

Soon, women realized that their struggles for empowerment were not all in vain. They received momentum again during the regime of an Army General, Pervaiz Musharraf, who supported women empowerment and encouraged them to participate in the media, sports and other socio-political activities. This movement to empower women is still in force, although to a lesser degree than before, along with the efforts of the WAF, who has been able to successfully get through women-friendly bills, for example, the Criminal Law Amendment Act (2004), the Anti-Sexual Harassment Bill, the Criminal Acid Act, Protection of Women Act, Status of Women Bill and sundry regulations condemning honor killings and other crimes faced by women in Pakistani society.

50 Ayesha Khan, Nida Kirmani, "Moving Beyond the Binary: Gender-based Activism in Pakistan", Feminist Dissent, 3/2018: 151-191.

51 I. Talbot, 234.

52 John Wilson, Vikram Sood, Akmal Hussain, Pakistan's economy in historical perspective: The Growth, Power and Poverty, Dorling Kindersley (Pvt) Limited, New DelhiWashington D.C. 2009, 220. 
Moreover, during the rule of the PPP under President Asif Ali Zardari (2008-2013) the number of women participating in political forums rose, with women being appointed to esteemed positions, like the Speaker of Parliament Dr. Fehmida Mirza, Foreign Minister Hina Rabbani Khar, Media Advisor Sherry Rehman ${ }^{53}$ and others who held prestigious positions within the government administration. Zardari also signed the bill on 'Protection against Harassment of Women at Workplace Bill 2009' that was adopted by the Parliament in $2010 .{ }^{54}$ In addition, he also signed two other bills in 2012 aiming at criminalizing the traditional practices of Vani, watta-satta, swara, marriage to the Quran, acid throwing etc. ${ }^{55}$ However, like the Nawaz government during its first tenure, the current government of the Pakistan Tehrik-e-Insaf (PTI) party also seems a bit conservative and restrictive. The current Prime Minister - Imran Khan - seems to favor Islamic ideals which might ultimately affect the status of Pakistani women in the future.

\subsection{Rights of Women under Sharia Law}

The role and status of women in the Muslim societies have been affected by the contradictory interpretations of the Holy Quran throughout the years. It must be kept in mind that all these interpretations of the versions of the Holy Quran are made by male scholars, which definitely impacts women and their status. As women in Muslim societies have always been kept away from seeking education, their capability to read and raise a voice against any of the interpretations impacting their lives seems greatly hindered. Their only source of knowledge and information was their father, husband or any other male member of the family. As a matter of fact, the differences of rights of men and women in Muslim societies stem from sexual, biological, and social realities, rather than a scientific basis.

The Holy Quran itself acknowledges the superiority of men over women and women over men in certain aspects with due regard to the natural facts. With regard to the superior position of men over women, the Quran states that men provide financial or economical support to the women. According to this argument, there seems to be no superiority of men over women based on natural facts, as this entirely economical factor

53 Reuters, "Sherry Rehaman appointed Pakistan's ambassador to US", DAWN, https:// www.dawn.com/news/675333/sherry-rehman-appointed-pakistans-ambassador-to-us, last visited 20.4.2020.

54 Shamimur Rahman, "Women's bill sets tough penalties", DAWN, https://web.archive.org/ web/20100131230825/http://www.dawn.com/wps/wcm/connect/dawn-content-library/ dawn/news/pakistan/04-zardari-signs-women-prot-bill-qs-08, last visited 20.4.2020.

55 Staff Report, "President signs two women's rights bills into law", Pakistan Today, https:// www.pakistantoday.com.pk/2011/12/23/president-signs-two-women\%E2\%80\%99srights-bills-into-law/, last visited 20.4.2020. 
is not an inherent thing. However, the Quran still awards slight superiority to men over women in both domestic as well as political domains. As for the domestic sphere, final power or authority shall be vested in one sex or the other, probably men as per the Quranic interpretation. Likewise, in the political domain, the final say shall also rest with the men, based on their comparative freedom from several natural boundaries which consume substantial female time and energy, enabling the men to devote greater attention towards political issues and matters. ${ }^{56}$ Similarly, after going through the interpretation (tafseer) of Quran by Mr. Siddique, a woman can rightly assume that the assurance provided in the Holy Quran of equality between both the sexes is not accurate. According to his tafseer, it is stated that although both sexes are equal, there are certain domestic, economic and political aspects where men lead women with a slight degree of superiority with regards to their sexual, biological, physical and mental acumen. The traditionalists also view equality and freedom as erroneous concepts, and postulate that Islam instead gives both the sexes their due in accordance with their position and nature. Women are primarily responsible for taking care of the family and once that is accomplished, they can participate in professional or communal activities. Whereas modernists and secularists believe that Islam contains the basic concepts of human rights and individual freedom. They consider both family and community significant in Islam, and therefore, expect both sexes to carry out their responsibilities equally in all professions, public life and political offices. It is substantiated by the practice of people during the times of Prophet Muhammad, when women even fought in his army, were appointed by him to be judges, and even led men in prayer. Therefore, any sort of discrimination is illegal in their view and they propose equal rights and opportunities as desirable. ${ }^{57}$

Since its inception, Islam was (and presently is) entirely male dominated, providing in-depth legislation favoring men over women in matters of dealing with marriage, divorce, property rights, inheritance etc. This legislation forms the core of family laws included in the Sharia law, which are considered to be one of the sensitive issues across Islamic countries in the modern era. As every society is posed with the issue of either lesser or greater adaptations, all Muslim countries have the same issue to deal with. Some of them propose the substitution of the old Sharia laws with a new, modern law code, while others seek interpretations of state law in such a way so as to conform to the Sharia law, making Qiyas an essential

56 M. Mazheruddin Siddiqui, Women in Islam, The Institute of Islamic Culture, Pakistan 1952, 23-24.

57 Cheryl Benard, Mapping the Issues: An Introduction To The Range Of Thought In Contemporary Islam, $1^{\text {st }}$ ed., RAND Corporation, Santa Monica 2003, 8-13. 
source of legal discretion. ${ }^{58}$ According to detailed teachings of Islam, it is clear, however, that Islam gives men superiority over women in matters of personal nature. Let's discuss these teachings in depth under the following sub-headings, reviewing the rights of women in matters related to marriage, divorce, property, inheritance etc.

\subsubsection{Marriage}

It is true that Islam provides women with rights relating to marital issues, yet certain cultural practices incur a heavy impact upon the offer and acceptance procedure past the Islamic prerequisites, and in several instances incur results in sheer derogation to the Islamic practices. ${ }^{59}$ Historians claim that the status of women before the advent of Islam was the same as that of animals, no less. That being said, these historians allege that the women in the pre-Islamic era enjoyed no legal protection, and had no rights. Men were allowed to marry as many women as they wanted (a practice known as polygamy), could divorce women with ease and buried female infanticide. But with the advent of Islam, the Holy Prophet brought an Islamic reform that aimed to bring potential changes to these immoral activities of the Arab pagans and their customs.

The Prophet brought reforms in the laws and customs relating to the family matters such as marriage, divorce, property, inheritance etc. According to his teachings of Islamic reforms, marriage is comprised of three main aspects to consider: legal aspect, social aspect, and religious aspect. Based on the legal aspect of marriage, it is considered as a contract in three senses: it requires an offer and acceptance of both parties; contains provisions for the breach; and allows for a revision or modification of these provisions acceptable to both parties. Although it is just considered as a contract in Islam, the general assumption makes it into a sacred covenant. ${ }^{60}$ In any case, in Islam, a wife possesses the rights as an heir and widow entitled to dower after the demise of her husband. She also has the right to retain the property of her deceased husband, only at such time when she becomes capable of collecting her dower / mehr. But as the majority of Islamic scholars favor the concept of mehr being non-inheritable (because it is not a lien), a wife's rights to the property of her husband remain questionable and controversial.

58 Charris Waddy, Women in Muslim history, Longman ELT, London 1980, 30-31.

59 Imani Jaafar Mohammad, Charlie Lehmann, "Women's Rights in Islam Regarding Marriage and Divorce", Journal of Law and Practice 4/2011, 1-2.

60 R. A. Nicholson, A literary history of the Arabs, Cambridge University Press, Cambridge 1969, 38 . 
Apart from this, the Islamic tradition also allows men to marry women to the count of four at the most, with the only condition of loving, caring, and supporting all the women equally. But this provision is not extended to the woman in Islam, as she can marry only one man. In case she marries a second man, she is believed to have committed bigamy and her children from the second marriage are deemed illegitimate, and can never acquire legality by any way afterwards. Although Islamic teachings speak of equality between the sexes, double standards are a common occurrence in the Islamic legal system. For instance, Muslim men are allowed to marry a woman of other faith like a Christian or Jewish woman, but the same is not applicable for women, as they cannot marry men outside of the Muslim faith. If a Muslim woman did dare to do so, she was declared an outcast and her marriage was deemed as invalid or void. This particular provision raised considerable controversy in the subcontinent during the times of British rule.

Moreover, there are some other kinds of marriage in Islam that form the basis of cruel practices, discriminating against women and favoring men alone. One such kind is nikahhalala (commonly referred to as tahleel marriage) ${ }^{61}$ and the other is contract marriage (also known as Mut'ah marriage). The former kind of marriage takes place when a woman who has earlier been divorced from her husband wants to remarry him. For that purpose, she has to first marry some other Muslim man, get that marriage consummated and seek divorce from him, in order to remarry her former husband. ${ }^{62}$ Although this kind of marriage has been declared haram (forbidden) by the hadith of the Prophet, ${ }^{63}$ it was still in practice during the earlier periods of Islam and a small Muslim minority practices it today as well. ${ }^{64}$

The latter kind of marriage takes place when a man wishes to marry a woman based on a contract, with mutual consent, for a specified time period and for such marriage the amount of mehr is specified and agreed upon in advance. ${ }^{65}$ When the time stipulated in the contract lapses, the

61 Shaheen Sardar Ali, Anne Griffiths, From Transnational Relations to Transnational Laws: Northern European Laws at the Crossroads, Routledge, 2016, Chapter 5.

62 Vatsala Singh, "What does Quran say about Nikah Halala? Will banning it help?", Bloomberg LP/The Quint, https://www.thequint.com/voices/women/so-what-does-thequran-say-about-nikah-halala-triple-talaq-polygamy, last visited 23.4.2020.

63 Yusuf Al-Hajj Ahmad, The Book of Nikah: Encyclopedia of Islamic Law, Darussalam Publishers, Volume II, 2014, 23-25.

64 Athar Ahmad, "The women who sleep with a stranger to save their mariage", $B B C$ News, https://www.bbc.com/news/uk-39480846, last visited 20.04.2020.

65 John L. Esposito, The Oxford Dictionary of Islam, Oxford University Press, Oxford 2003, 221. 
marriage stands void and such a woman gets divorced. This practice is still considered valid by a small Muslim minority sect - the Shiite Sect. According to them, mut'ah marriage comprises certain preconditions: the woman shall not be married; she should be a chaste and pious Muslim, or belong to People of the Book (Ahl Al-Kitab); she must seek her guardian's approval in case she has never been married before; and if she has no guardian, then she must be a non-virgin, according to Islam, to do so independently. When the contract expires, the marriage dissolves and the woman has to undergo a period of abstinence (four months, ten days, also known as iddah) from further marriage or sexual intercourse. The purpose of iddah is to provide sufficient time to ascertain the paternity of the child if the woman gets pregnant during the period of contract marriage. ${ }^{66}$

The Shiites support for the contract marriages is based on the teachings of the Holy Quran, hadith of the Prophet, history, cultural and moral grounds. ${ }^{67}$ According to them, the verses of Holy Quran take superiority over any other sources of Islamic laws, thus justifying their practice of mutah marriages through the Holy Quran in Surah An-Nisa, verse 24 (also known as the verse of Mut'ah).

"And also prohibited to you are all married women except those your right hands possess. This is the decree of Allah upon you. And lawful to you are all others beyond these, provided that you seek them in marriage with gifts from your property, desiring chastity, not unlawful sexual intercourse. So for whatever you enjoy of marriage from them, give them their due compensation as an obligation. And there is no blame upon you for what you mutually agree to beyond the obligation. Indeed, Allah is ever Knowing and Wise."

\subsubsection{Divorce}

As Islam considers marriage a contract between two parties, therefore, it attaches high repute and respect to it. Although divorce carries no immoral connotation, it is strongly discouraged in Islam, as it demolishes the existing family set-up. The abhorrence towards the practice of divorce is clear from the numerous sayings of the Holy Prophet himself, for instance 'the most repugnant thing made lawful in the sight of God is divorce', or 'marry but do not divorce, because God does not like men and women who relish variety in sexual pleasure'. In spite of this dislike, divorce does take place and it can be carried out in three ways: by the death of either of the spouses; by the act of parties; and through judicial procedure. Firstly, when either of them, i.e. the husband or wife dies, the marriage stands

66 R. A. Nicholson, 8.

67 Achim Rohde, State-Society Relations in Ba'thist Iraq: Facing Dictatorship, Routledge, 2014, 171. 
dissolved lawfully. But the consequences of remarrying after the death of a spouse vary for men and women. In case a wife dies, the husband is at free will to remarry immediately, but conversely speaking, a wife cannot do so, as she has to observe the 'iddah' before remarrying another man. In case the wife was found pregnant at the time of her husband's death, she must wait till the delivery of the child before remarrying.

Secondly, divorce can also take place by the act of the parties. That means the husband can divorce his wife by pronouncing the word 'talaq' thrice and the marriage stands dissolved. The word talaq indicates the supreme authority of a husband that he possesses over his wife to annul their marriage at any time he so desires, without seeking his wife's approval, or presence at the time of pronouncing talaq. The divorce is immediately in effect once the word 'talaq' is used in the right connotation with absolute clarity and unambiguity. ${ }^{68}$

However, this concept of triple talaq which means that the divorce is valid as soon as the husband pronounces the word 'talaq' thrice, does not find its parallel in the teachings of the Holy Quran, as interpreted by the Sunni School of thought. In this regard, the practice and ideology of the Muslim minority Shiite Sect is deemed to be in accordance with the true interpretation of the verses of the Holy Quran from both Surah Talaq and Surah Al-Baqra. Therefore, in order to comprehend the teachings of Islam regarding divorce, it would be very useful to comprehend their meaning in depth by looking at some of the verses of the Quran below:

- Divorce may be pronounced twice; then the wife may either be kept back in fairness or allowed to separate in fairness. ${ }^{69}$

- And the divorced women (after the pronouncement of the divorce) must wait for three monthly courses...and their husbands are fully entitled to take them back (as their wives) during this waiting period, if they desire reconciliation. ${ }^{70}$

- Then, if the husband divorces his wife (for the third time), she shall not remain lawful for him after this divorce, unless she marries another husband... ${ }^{71}$

- When you marry the believing women, and then divorce them before you have touched them, they do not have to fulfill a waiting period, the completion of which you may demand of them. ${ }^{72}$

68 Sir Wilson Roland Knyvet, Anglo-Muhammadan Law, Law Publishing Company, 1930, 61.

69 The Holy Quran, Surah Al-Baqarah, Verse 229.

70 The Holy Quran, Surah Al-Baqarah, Verse 228.

71 The Holy Quran, Surah Al-Baqarah, Verse 230.

72 The Holy Quran, Surah Al-Ahzab, Verse 49. 
- And if those of you who die, leave wives behind, the women should abstain (from marriage) for four months and ten days. ${ }^{73}$

The laws relating to divorce mentioned in the above verses prescribe the following rules:

i. A man (husband) can utter the word 'talaq' thrice upon his wife.

ii. If a husband utters talaq for once or twice, he still bears the right to keep his wife within the prescribed waiting period, and if after the expiry of this waiting period both of them want to remarry, they can do so and there lies no condition of Nikah-halalah (Tahleel marriage) for that. But in case the husband utters talaq thrice upon her wife, he loses any legal right on his wife and has to undergo nikahhalalah to remarry her.

iii. The concept of the waiting period exists for a woman who undergoes menstruation and with whom the marriage has been consummated. Therefore, when her husband dies, she is required to pass three monthly menstruation cycles.

iv. There exists no waiting period for a woman who has never consummated her marriage or who became a divorcee even before getting touched, therefore, she can remarry whenever she wants.

v. The waiting period of a widow woman is said to be four months and ten days. ${ }^{74}$

Thirdly, a divorce can also take place through a judicial process whereby a wife seeks the court's help to dissolve her marriage either by talaq-itafwid (delegated divorce) or through a court decree. Talaq-itafwid or delegated divorce is a judicial process where the wife is given the right or power to divorce by her husband, either as a condition at the time of marriage or sometime after the marriage through mutual consent. The provision is based on certain prerequisites if a wife needs to call out for this kind of divorce. There are two primary prerequisites for the exercise: 1) the delegated right to divorce must be based on some reasonable grounds; and 2) it must not be unconditional or absolute. In contrast to the husband, the wife is under mandatory obligation to present evidence in her appeal for divorce and her appeal must be adjudged based on the parameters of reasonable grounds and public policy. Thus, this haphazard opportunity of delegated divorce provides women with just a nominal way of acquiring freedom from her unsatisfactory marital life. This deliberate

73 The Holy Quran, Surah Al-Baqarah, Verse 234.

74 Abul A'ala Maududi, Syed Abu-Ala' Maududis: Introductions to the Qur'an, Amazon 2012, Chapter 65. 
display of inequality laying the onus of proof on women showing evidence of a breach, and proving such breach liable for her claim of separation or divorce is known as the 'the most potent weapon in the hands of a Muslim husband. ${ }^{75}$

Another way for a woman to seek divorce is through a court decree, which often requires her to waive the entire or part of her mehr (dower). In other cases, she may also be compelled to seek her freedom by giving bribe in the form of money to her husband to free her from the marital bond. In addition, if a court finds out that the woman asking for a divorce reserves no valid grounds and her claim is merely based upon being the victim of marital rape; the court may demand her to give more than just her dower. ${ }^{76}$ In deciding the validity or reasonableness of grounds for divorce, the court is guided by the teachings of Islam which recognize the following list of grounds as reasonable for seeking divorce: husband's refusal to provide economic sustenance; change of religion; impotence; infectious diseases etc.

Besides, divorce may also take place by mutual consent of both parties, that is if the husband and wife mutually agree that their marriage is no more workable and should be dissolved, then each of them have to return their consideration, given at the time of contracting marriage. Once the parties return those considerations, the marriage stands dissolved. Moreover, Islam also provides another method of divorce i.e. through the process of annulment or abrogation (referred to as faskh) of a marriage. For that purpose, both the parties have to appear before an arbitrator / judge to get their marriage annulled. The reason behind this kind of separation or divorce lies in the Holy Qur'an, Surah Nisa, verse thirty-five which states:

'And if you fear dissension between the two, send an arbitrator from his people and an arbitrator from her people. If they both desire reconciliation, Allah will cause it between them. Indeed, Allah is ever Knowing and Acquainted with all things.'

According to this verse, if the parties wish to separate, they may call upon an arbitrator who shall hear the claims of both the parties and decide accordingly. But if, however, the husband withdraws from his previous claim while the trial is ongoing, the wife shall not be entitled to freedom and dissolution of marriage.

75 Asaf A. A. FYZEE, Outlines of Muhammadan Law, Oxford Publishers, Oxford 1964, 151-152.

76 C. Waddy, 77-79. 


\subsubsection{Custodial Rights}

According to the teachings of Islam, a mother enjoys high status in the society and this has been proved by the oft-repeated hadith of the Prophet (PBUH) himself stating paradise lies at the feet of mothers. ${ }^{77} \mathrm{~A}$ mother experiences an intimate, close and most informal relationship with her children. She is responsible for providing her children with all kinds of supports in their lives, including emotional, social or even financial. But all the praises for a mother become non-existent from the moment her marriage falls apart, either due to divorce or due to natural causes (death of her husband). In any of the cases, the rights of a mother for her children's custody become exceptionally limited.

For instance, in case a woman is divorced at a time when her son and daughter are of two and seven years of age, respectively, then her right to custody over her children no longer remains with her, according to Islamic law. The custody of the children will automatically be given to her husband and she would not be allowed to visit them again. As Islamic law is patriarchal by nature, it does not consider the mother a natural guardian of the children. The father - or his executor, in the case of his death - becomes the legal guardian of the children. The mother only enjoys a limited custody of her children that is up to the age of two years for the son and seven years for the daughter. These limited and biased women's custodial rights once again point to the inequality existing between the sexes in Islam. However, this practice relating to the custodial rights over children find no support from the verses of the Holy Quran. Therefore, it is assumed that these practices have evolved as a result of the Sunnah of the Prophet, Muslim culture, fatwas of the ulama or religious scholars.

Although the Islamic teachings claim equality for men and women, actions speak louder than words in the matters of marriage, divorce and child custody. In all these matters, men are given greater rights and power as compared to women. Islam recognizes marriage as a civil contract to which both the contracting parties agree of their own free will and therefore, are at freedom to dissolve such a contract any time they so desire, without feeling the guilt of committing some moral wrong. Even after that, a wife's free will in all these matters is gravely influenced by two important factors. Firstly, in case a woman is divorced, the husband keeps the right of custody over their children. Here one may ask how much freedom a woman really enjoys in seeking divorce from her husband, knowing the fact that she would no longer have the right of custody over her children, or even permission to visit them ever again. She is only allowed

77 Sunan An-Nasai, Hadith 20, The Book of Jihad, Chapter 6. 
to leave with her clothes and some personal belongings. Apart from the fact that the wife has her mehr (dower) expressly provided when contracting marriage, she is habitually compelled to waive her right to that mehr in exchange for her husband's approval to seek divorce.

Secondly, in case of divorce, a woman is faced with the struggle for economic survival as well as taking care of her children. That is, after divorce a woman losses both a companion and the source of income or livelihood. Because she has not worked before (which is more often than not the case in Muslim societies), she lacks the necessary skills to obtain employment opportunities. Thus, in order to sustain herself and the children under her custody till they reach of age, she has only two options to survive i.e. to become a beggar or a prostitute. Since these two options are not acceptable for most women, they opt for remarriage. But as soon as she chooses to remarry, she loses the custodial rights over her children then and there, that is, even sooner than in the time allowed by Islamic law. In these circumstances, one can again question the degree of freedom provided to a woman in comparison to a man, who has no consequences to deal with after getting divorced and is at free will to remarry again, knowing that the children would come into his permanent custody given the due time under Islamic law. ${ }^{78}$ Moreover, a divorced woman is seen with abhorrence in the society and it seems like an uphill battle for a divorced woman to remarry, unlike a divorced man. Here again, even though Islam allows women to remarry, the society or culture do not make this path easy for women, and prioritize their own interpretations of Islamic teachings instead.

\subsubsection{Employment Rights}

The Sharia law provides women with the right to work but it is subject to a number of factors and strict circumstances. Most Muslim countries, however, do not provide women an equal share in job prospects as opposed to men, due to the fact that women are by and large prohibited from participating in public life the way that men do. The Quran considers a working woman as a source of enticement for any man working alone and in close proximity to that woman. Moreover, the Quran stresses the fact that a woman must guard her honor by being modest while pursuing a job befitting this requirement. Thus, it is suggested that women should stay within the bounds of their homes and take care of the home chores. Keeping in view the teachings of the Holy Quran, most Muslim women do not pursue any kind of job, believing it is an immoral act. Con-

78 Nayer Honarvar, "Behind the Veil: Women's Rights in Islamic Societies", Journal of Law and Religion 6/1988, 355-387. 
sequently, when these women opt to stay in, they lose the opportunity to acquire any sort of property for themselves and remain completely dependent on the male members of their family, be it their father, brother, husband or son, etc. ${ }^{79}$

\subsubsection{Property Rights and Inheritance}

Since its inception, Islam has treated both men and women as distinct entities. Even after marriage, both sexes do not enjoy equal share of each other's material possessions. That is, each of them maintains absolute control over his/her personal or real property. This notion of property ownership in the common law of England during the $19^{\text {th }}$ century was quite different to that of the Islamic ideology. The English law considered both the husband and wife as a single entity or unit led by the husband, who possessed absolute control over his wife's properties and was in a position to deprive her of her property rights as the law did not consider her as an autonomous legal entity. ${ }^{80}$

As stated previously, the matrilineal system of kinship held a woman as the head of her family and awarded her many rights, including the right to own property. In contrast, the patrilineal system of kinship considered women as nothing more than animals principally used for breeding and labor on the farm. The Prophet Mohammed chose the patrilineal system as the basis for his new religion upon which he implemented his Islamic reform. However, he did maintain the woman's right to buy and sell property and to establish a business without any male relative's consent, direction, or involvement. For instance, the Holy Prophet's own first wife Khadijeh was a rich and respected woman among the Quraish tribe, who owned and operated her own import and export business. In the course of her business, she had to maintain contact with men and employed a large number of men in her business, including the Prophet himself. ${ }^{81}$

The right of women to own property is also recognized by the Holy Quran. This recognition is expounded by the Quran itself which mentions some women holding esteemed positions in the times of the Holy Prophet, allowing them, afterwards, to acquire property. Generally, the Islamic law is clear about the rights of women in relation to holding, using

79 Shampa Mazumdar, Sanjoy Mazumdar, "Rethinking Public and Private Space: Religion and Women in Muslim Society", Journal of Architectural and Planning Research 18/2001, 302-324.

80 Ronald J. Daniels, "The Legacy of Empire: The Common Law Inheritance and Commitments to Legality in Former British Colonies", The American Journal of Comparative Law 59/2011, 111-178.

81 S. Mazumdar, S. Mazumdar, 302-324. 
and disposing of property, but these laws become intricate when explained through the tafsir of scholars from various schools of thoughts in Islam. In addition, Islamic law also recognizes the fact that a woman must be given her earnings, which can be transferred to her husband if she desires it of her own free will. Considering the fact that Islam requires women to be modest and restrict their public appearances, the right to property ownership seems contested as such a right can only be acquired when women are released from the bonds of restrictions and allowed to manage their property themselves, without the need of any male relative.

Since Islam follows a patriarchal linage, the man is considered the head of a family and thus possesses the right to property ownership. Inheritance is one form of property ownership and Islam gives immense favors to men with regard to inheritance. ${ }^{82}$ The law of inheritance is quite extensive and provides indepth details in Islam. Religious scholars frequently refer to the saying of the Prophet with regards to the significance of inheritance laws, 'Learn the laws of inheritance, and teach them to the people; for they are one half of useful knowledge. ${ }^{83}$

The law of inheritance in Islam consists of two distinct elements: the pre-Islamic customs of Arabia, and the Islamic reforms introduced by the Prophet. In broader sense, the law of inheritance requires three things: certain individuals are given a specific share, according to the guidelines in the Quran; the residue is given to the agnatic heirs; and bequests are limited to one-third of the estate. A comparative review of the pre-Islamic and Islamic principles of the inheritance laws shows that the Quran corrected the inequalities and economic injustices which existed in pre-Islamic Arabia concerning the distribution of wealth. A summary of the two principles is as follows: ${ }^{84}$

i. Pre-Islamic Law of Inheritance based on the customs of Arabia:

a. The nearest male agnate or agnates succeeded;

b. Females and cognates were excluded;

c. Descendants were preferred to ascendants, and ascendants to collaterals; and

d. Where the agnates were equally distant, the estate was divided per capita.

ii. The Islamic Law of Inheritance:

a. The spouse was made an heir;

82 Ownership of Property in Islamic Law, 2018.https://www.ukessays.com/essays/anthropology/property-ownership.php, last visited 20.4.2020.

83 A. Maududi, 823.

84 Ibid., 602 etc. 
b. Females and cognates gained the right to inherit;

c. Parents and ascendants were given the right to inherit even when there were male descendants;

d. As a rule, a female was given one half the share of a male; and

e. Rule of exclusion: in Islam every individual, including an unborn child (provided it is born alive), is given the right to inherit. However, there are certain categories of individuals who are barred or excluded from the list of inheritance. This exclusionary rule is applied in circumstances involving differences in religion, homicide, slavery, and legitimacy ${ }^{85}$ An individual may be excluded in one of two ways: imperfect and perfect. An imperfect exclusion is basically a change of position or status in the line of succession, e.g., a female by herself is a Quranic heir, but if she has a brother then she is excluded as the Quranic heir and admitted as an agnatic heir. The perfect exclusion is based on some legal cause and excludes people who, under normal circumstances, are eligible to inherit. Some of the more important situations under which the perfect exclusionary rule is applied include: a non-Muslim cannot inherit from a Muslim; a person who causes the death of another, whether it be intentionally or unintentionally, cannot inherit from the estate of the deceased; a slave cannot inherit from a free man (this is an ancient law, no longer existent in modern day Muslim societies); an illegitimate child can only inherit from the mother's estate and not the father's. This is one exception where the natural relationship determines the right to inherit. Islam does not recognize illegitimacy altered into legitimacy through the process of legislation. In some Muslim societies, the old customs still exist, and females face exclusion and their share of inheritance is calculated into that of the male heirs and it's an example of imperfect exclusion. ${ }^{86}$

Although women possess the right to inherit a certain amount of share in the property of their deceased family member, their share is mostly half of the share of men in the family. For instance, a daughter bears the right to inherit from her deceased father's property, but the share is half of what the son inherits. To put it in another way, the inheritance is divided in such a way that two shares of it go the son and one to the

85 Papa Murphy, Inheritance Laws in an Islamic Society: Islamic Cultures Are Distinct in Everyway, iUniverse, US 2012, 177.

86 Alexander David Russel, Muslim Law: An Historical Introduction to the Law of Inheritance, Routledge, 2013, 227. 
daughter. The reason behind this unfair provision for inheritance is based on the presumption that women (daughters in this case) have no duty to look after and manage a family in the same way as men do (sons in this case). In addition, some women suffer from a complete denial of their right to inheritance in several conservative Muslim countries which keep in view these unfair Sharia law provisions and customary practices. The reasoning behind this is that women offer no help in looking after the family; therefore, they should not be given any share in the inheritance property. Northern Nigeria, where Islam is practiced, is a living example of the stated fact, with most of the law courts prohibiting women from acquiring any right to inherit property. In most cases, the process of inheritance is carried out in theory only and not in practice. That means the women are merely informed that they possess the right to inherit a certain part of the property, which in the majority of cases is not given to them at all. The right to property ownership has always been considered a man's business, as women are deemed weak and entirely dependent on men, needing them to manage the property and issues relating to such.

In 1995, Annelies Moors ${ }^{87}$ explained that the women under Islamic law possess inheritance rights which are usually more restricted than the rights of men. The preference is generally given to men, which is quite clearly seen in the laws of inheritance in Islam. To prove this, she refers to the share of widows and daughters, who inherit a much smaller share than any male member of the family. In case a woman's husband dies, it becomes very difficult for her to inherit exclusive rights to her husband's property. This is done to keep such a widow from getting remarried, and taking the entire property out of the hands of the deceased husband's family. It is deemed better to keep her under the protection of the male members of the deceased husband's family, so that the property stays within his family (basically the men). Islam entitles the wife to one-eighth of the property of her husband, in case she had children with her deceased husband and to one-fourth, in case she is childless when her husband dies, while daughters are entitled to half the share in comparison to their brothers' share. Moreover, in case a father has only one daughter as his child, she would inherit only half of his property and the rest would be given to his male relatives in the family. However, this is not true in case of an only son, as he gets the entire property of his deceased father, which reflects the biased teaching of Islam against women. The logic behind the difference in the shares of a widow is that the property she inherits with children would go to her children, particularly the boys, and even that share is usually smaller than it should be and often withheld due to the fear that she

87 Annelies Moors, Women Property and Islam: Palestinian Experience 1920-1990, Cambridge University Press, Cambridge 1995, 286. 
might get remarried. In the case of a childless widow, she is generally given nothing in the property ownership.

\subsubsection{Testimony of Women}

In Islam, the status of women's testimony is highly disputed, ranging from a complete rejection in particular legal areas, to a conditional acceptance in a discriminating manner (half the worth, etc.), to a complete acceptance without any bias towards gender. The Islamic law defines testimony (shahada) as an attestation with regard to a right of a second party against a third party. It co-exists with other forms of evidence such as the oath, acknowledgement and circumstantial evidence, in order to prove a case. A testimony should rest upon certain knowledge of the event in question, and it cannot be based on mere speculation. ${ }^{88}$

The testimony of women varies in accordance with issues and circumstances of the case in question. In case of a witness for financial matters/documents, the Quran requires two men or one man and two women. The second chapter of the Holy Quran, Surah Al-Baqarah, Verse 282 provides the basis for the above-mentioned rule that two women are the equivalent of one man in providing a testimony in financial situations as a witness. ${ }^{89}$

'O you who believe! When you contract a debt for a fixed period, write it down. Let a scribe write it down in justice between you. Let not the scribe refuse to write as Allah has taught him, so let him write. Let him (the debtor) who incurs the liability dictate, and he must fear Allah, his Lord, and diminish not anything of what he owes. But if the debtor is of poor understanding, or weak, or is unable himself to dictate, then let his guardian dictate in justice. And get two witnesses out of your own men. And if there are not two men (available), then a man and two women, such as you agree for witnesses, so that if one of them (two women) errs, the other can remind her.'

This saying of the Quran has also been interpreted by several Muslim scholars in order to imply testimony of two women being equal to a single man's. The tafsir of Ibn Kathir states that Allah requires that two women take the place of one man as witness, because of the woman's shortcomings, as the Prophet described. ${ }^{90}$ Ibn al-Qayyim also comments on the aforementioned verse as follows:

88 Wael B. Hallaq, Sharīa: Theory, Practice, Transformations, Cambridge University Press, Cambridge 2009, 347.

89 Mohammad Fadel, "Two Women, One Man: Knowledge, Power and Gender in Medieval Sunni Legal Thought", International Journal of Middle East Studies 29/1997, 185-204.

Ibn Kathir, Tafsir Ibn Kathir, Surah Al Baqarah, Part II. 
'There is no doubt that the reason for a plurality of women in the Quranic verse is only in recording testimony. However, when a woman is intelligent and remembers and is trustworthy in her religion, then the purpose of testimony is attained through her statement just as it is in her transmissions in religious contexts. ${ }^{\text {, }}$

In addition to the restriction declared in financial matters, a large number of classical Muslim scholars are prejudiced against women testimonies in matters of criminal cases too. A twelfth century Maliki jurist - Averroes - stated that jurists of his time disputed the status of women in matters of hudud and criminal punishments for serious crimes. He further stated that some of the jurists were of the opinion that the testimony of a woman was entirely unacceptable in these matters. However, he stated that a school of thought referred to as Zahiris believed in the testimony of two or more women testifying together with a male witness, and considered it acceptable even in cases regarding financial transactions described above. $^{92}$ One of the most influential Islamic scholars, Ghamidi, rejected further extending the implementation of the Quranic verse (mentioned above) to incidental events, claiming that the specific verse was limited to the particular topic of financial or contractual witnesses. In contrast, however, there are some hadiths that confirm the acceptance of only one female testimony in the instances of one murder and the assassination of the third Caliph of the Islamic state - Hazrat Usman. Respectively, the acceptance of these testimonies led to the death penalty for the murderer and an initiation of a campaign against the state.

Apart from financial matters, Muslim scholars also differ on the status of women's testimony in other issues and on whether the interpretation of verse 282 for financial transactions should be applied to other cases as well or not. This is particularly true in the matters relating to bodily affairs such as divorce, marriage, freedom of slave, and restitution of conjugal rights. According to Averroes, the Imam of the Hanafi school of thought believed in the acceptance of women testimony in such matters. In contrast, the Imam of the Maliki school of thought believed in the non-acceptance of women's testimony in such matters. For certain cases, however, Muslim scholars agree on the acceptance of women's testimony alone, where the men have no prior knowledge of circumstances involving the physical handicaps of women or the crying of a baby at birth etc. Ibn Qudamah, in his famous compendium on Islamic jurisprudence al-Mughni,

91 Nazir Khan, Tesneem Alkiek, Safiah Chowdhury, "Women in Islamic Law: Examining Five Prevalent Myths", https://yaqeeninstitute.org/nazir-khan/women-in-islamiclaw-examining-five-prevalent-myths, last visited 20.4.2020.

92 Ibn Rushd, Bidayatu'l-Mujtahid (1 ${ }^{\text {st }}$ ed.), Daru'l-Ma'rifah, Beirut 1997, 311. 
stated that in matters of nursing, childbirth, menstruation, chastity, and physical defects, a male witness alone is not accepted, while a single female witness is. ${ }^{93}$ In these situations, the testimony of a woman becomes equal to that of a man, and her testimony can also invalidate a man's testimony where he accuses his wife of unchastity.

\subsection{Rights of Women under Anglo-Saxon (Common) law}

Despite the stringent and unfavorable Sharia laws, women have been provided with necessary legal safeguards to protect themselves under the common law in practice in Pakistan. This common law has been a legacy of the British since their rule in the undivided subcontinent. As Pakistan bears a combination of Sharia laws with the Anglo-Saxon laws, women in Pakistan enjoy rights under both of these systems of law. Although several religious scholars and extremist view such a bifurcation as going against the true rule of Islam in the country, the Constitution of Pakistan provides essential fundamental rights to both sexes, without any sort of discrimination. Therefore, over the times, women have been provided with rights other than Islamic rights, by way of a common legal system in the form of legal rights/safeguards provided in the Constitution and Legal instruments of the country. A legal right has been defined in Black's Law Dictionary as: "A right created or recognized by law". Following are the different categories of legal rights for women in Pakistan:

i. Rights provided to women under Constitutional law.

ii. Rights provided to women under Criminal Law.

iii. Rights provided to women under Civil Law.

iv. Rights provided to women under Family Law.

\subsubsection{Rights provided to women under constitutional law}

The Constitution of the Islamic Republic of Pakistan guarantees fundamental rights to every citizen without discrimination on the basis of gender. Foundation of the Constitution of Pakistan (1973) is embedded in Islam, a religion that has recognized all human rights, women's rights included, 1400 years ago. According to Article 25 of the Constitution of the Islamic Republic of Pakistan, 1973 (hereinafter referred to as "The Constitution") all citizens are equal in the eyes of law and there must not be any discrimination on the basis of sex. In the urban areas of Pakistan, women are participating in every field of life, working for the social and economic development of the society. At the same time, the position of women in

Ibid., 311. 
rural areas is deplorable, amidst heinous anti-woman practices like forced marriages, rape, vigilante justice, acid attacks, mutilations, honor killings, sawara, karokare and vani, etc. ${ }^{94}$ The Constitution has guaranteed twenty one fundamental rights, which are as follows:

a. Rights of life and liberty

b. Rights to Equality (irrespective of gender, race, religion, caste, residence)

c. Rights to Freedom: Freedom of movement (Art. 15); Freedom of assembly (Art. 16); Freedom of association (Art. 17); Freedom of trade, profession, etc. (Art. 18); Freedom of speech (Art. 19); Freedom of religion (Art. 20) ("freedom of religion applies to minorities as well as various sects of religion"), Protection against taxation on basis of religion (Art. 21); and Protection of religious and educational institutions (Art. 22).

d. Right to Education: (Art. 25-A).

e. Rights to Property: Freedom to acquire property (Art. 23); and Protection of property rights (Art. 24)

f. Rights to Culture: Preservation of language, script, and culture, etc. (Art. 28)

g. Social Rights: Freedom from slavery (Art. 11); and Freedom from forced Labor (Art. 11)

h. Right to Constitutional Remedies to Protect Fundamental Rights: Under Article 199 of the Constitution, every citizen of Pakistan can invoke the writ jurisdiction of the high court and seek remedy against infringement of fundamental rights guaranteed thereunder.

\subsubsection{Rights provided to women under criminal law}

Women have been provided rights in criminal matters by way of various Statutes, namely:

a. Pakistan Penal Code (PPC), 1860: Sections 310, 310(A), 332, 336(A)(B), 354, 354(A), 365(B), 366(A)(B), 367, 371(A)(B), 375, 376, 493, 496(A)(B)(C), a new chapter about 'Offences against Women' Sections 498(A)(B)(C), 509, and a Bill on Domestic Violence, according to which a victim can file a case before the Court of law which would be decided as early as possible.

b. Criminal Procedure Code (Cr.P.C), 1898: Sections 52, 497, 167, 203(A)(B)(C).

94 Dr. Abdul Razak Shaikh, "Women's status in Pakistan", DAILY TIMES, https://dailytimes.com.pk/362564/womens-status-in-pakistan/, last visited 20.4.2020. 
c. Offences of Qazf (Enforcement of Hadd) Ordinance, 1979: Sections 7, 14 .

d. Rights of Women Prisoners: Women prisoners enjoy same rights as are provided to men prisoners. According to Cr.PC and the Jail Manual, women have every sort of protection in jail. In the same way, they can pursue their cases, file appeals before the competent Court of law and they also have the right of remission during their imprisonment on different occasions.

\subsubsection{Rights provided to women under civil law}

Women have also been provided with civil rights through several Statutes, for instance:

a. Code of Civil Procedure, 1908: Section 56 provides that a woman cannot be sent behind bars in execution of decree and in financial matters.

b. Factories Act, 1934.

c. Married Women Property Act, 1874: This enactment protects the rights of a married woman with respect to her property (moveable or immovable), earnings and wages.

d. Mines Maternity Benefit Act, 1941.

e. The Maternity Benefit Ordinance, 1958.

\subsubsection{Rights provided to women under family law}

Women also possess rights under various family law Statutes or Acts, e.g.:

a. The Dissolution of Muslim Marriage Act, 1939: Section 2.

b. Muslim Family Laws Ordinance, 1961: Sections 5, 6, 7, 8, 9 and 10.

c. The West Pakistan Family Courts Act, 1964: Section 5, schedule 1, part 1, which provides rights to women in the following matters under the jurisdiction of family Courts: dissolution of marriage (including Khula), dower, maintenance, custody of children (visitation rights of parents in case of separation of parents), guardianship, recovery of dowry articles, and personal property and belongings of a wife.

d. The Guardians and Wards Act, 1890: In case of separation between the spouses, the mother has the legal right to keep the custody of her son till the age of 7 , while her daughter shall remain in her custody till marriage. However, in this rule the paramount 
consideration is the minor's welfare. In any case, though, all the day to day expenditures of the minor whatsoever, such as feeding, clothing, lodging, education and health, shall be borne by the father. If the father fails to fulfill this liability, the minor may seek help from the Court and the Court may fix a quantum of maintenance allowance, keeping in view the standard of life of both the families; coercive measures may also be used to recover the allowance from the father. Provided that the minor has not attained the age of seven (if it's a boy) or the age of 16 years (if it's a girl), the Court shall, on the first date of hearing, pass an interim order for the custody of minor to the mother and visitation rights of the father.

e. Child Marriage Restraint Act, 1929: Marriage of girls during childhood is prohibited. The parents and the nikkahkhwan both are liable to be punished with imprisonment and a fine if they are involved in arranging the marriage of a girl who is under sixteen years of age. The minimum marriage age was extended to 18 years through an amendment in family law.

f. Dowry and Bridal Gifts (Restriction) Act, 1976: Sections 3, 6, and 9.

\section{CASE-LAW STUDY}

In the previous sub-section, women's status and rights have been discussed in detail along with a brief historical overview. In this section, the primary focus is on the court practice with regard to women's rights in matters of contractual nature, keeping in view the Sharia and Common law system. The aim is to reflect the working and interconnected nature of both legal systems in the context of women in Pakistan.

Protecting the rights of women in Muslim societies is a subject of scholastic debate within the contemporary legal scholarship. In Pakistan, the debate is even more hectic, especially in the circumstances of a constitutionally mandated Islamization process. After Pakistan emerged on the world map, this process was initiated and accelerated by Gen. Zia's military rule (1977-88). The degradation of women's rights and status is perceived to be one of the significant consequences of this process. One of the misconceptions widely prevalent about women in Pakistan is that they do not enjoy equal legal protection. The aforementioned provisions in sub-section 2.3 provide adequate constitutional guarantees for the protection of women's rights in Pakistan. Besides such express provisions for the elimination of discrimination in the Constitution, it can be seen that the courts have not fully protected the rights of women in Pakistan. There 
is still more work and effort needed to accomplish the goal of equal status and rights for the women in the country.

Nevertheless, the Supreme Court of Pakistan has been continuously striving to bring the inequality gap regarding the status and rights of women to a minimum, so that women can enjoy their rights as sanctioned by the law of the land i.e. the Constitution. For that purpose, some of the cases and/or judgments of the Supreme Court are provided to highlight its progressive role in the promotion of women's contractual rights in a mixed legal system, comprising of Sharia and Common legal system. ${ }^{95}$ In the following cases, it can be seen that the Supreme Court was fairly consistent in supporting and securing women's rights within the constitutional framework. It has appeared to follow a progressive interpretation of Islamic law by applying istihsan or juristic discretion to solve the maslah or problem/issue. In short, all the efforts of the apex court highlight its commitment to uplift women's status largely through the constitutional parameters, as shall be evidenced from the cases/judgments cited below.

In the Shirn Munir ${ }^{96}$ case, there was a controversy related to discrimination on the basis of sex in the admission or enrollment of female students in educational institutions. The context of the case was that some educational institutions set a quota for both males and females in order to deprive female students of securing the admission they were otherwise entitled to. The Supreme Court held that no discrimination based on gender could be allowed except on the grounds of reasonable and intelligible classification. Coeducation is permitted and the settings of gender-based admission quotas are directly contrary to the requirements of Article 25(2) unless they are justified as a protective measure for women and children under Article 25(3). The Constitution assumes that women and children need protection rather than males, and as long as the same constitutional assumption continues, the court cannot reverse it by giving males protection at the cost of women and children.

Hafiz Abdul Waheed ${ }^{97}$ is one of the most celebrated cases concerning women's rights in Pakistan. In this case the dispute resolves over an adult girl's right to marry once and for all of her own free will and without a wali or guardian's consent. The Supreme Court held that the marriage was not illegal because of the presumed lack of consent of a wali. The court relied specifically on a number of Federal Sharia Court

95 Shahbaz Cheema, "Protection of Legal Status of Women in Pakistan: An Analysis of the Role of Supreme Court", International Journal of Physical and Social Sciences 4/2014, 616.

96 Shrin Munir and others v. Government of Punjab and Another, PLD 1990 SC 295.

97 Hafiz Abdul Waheed v. Asma Jehangir, PLD 2004 SC 219. 
judgments that an adult sui juris Muslim girl can contract a valid nikah or contract on her own.

In the Rafique $\mathrm{Bibi}^{98}$ case, the issue of delay in registering an FIR for alleged manipulation of income records, depriving a woman of her due inheritance share of immovable property was brought before the Supreme Court. The Court observed that it had always stressed the protection of women's rights related to land property in particular. Women have the right to petition for their civil rights in the courts, and if such a case has been brought before the courts, it would have to be dealt with in compliance with the law; relief could not be refused based on technicalities alone.

In another case, Fazal Jan ${ }^{99}$ addressed the rights of illiterate pardanashin (veiling) women in property matters. The Supreme Court noted that the petitioner was not expected to conduct a complicated case herself, so it was in the interests of justice that a competent and experienced civil lawyer should assist her. Such assistance would be considered in accordance with her fundamental rights, as provided for in Article 25(3).

The competence of a woman to be Pakistan's prime minister was disputed in the Inquilabi Labor Party and a statement was sought that a woman could not be head of an Islamic state, minister or member of the Provincial or National Assembly as it is against the spirit of the Constitution and the Quran and Sunnah. The court held that it is clear that the Constitution it self envisages "Muslim" as meaning a "person" that could not be restricted to men by any means. ${ }^{100}$ Thus, the court concluded that there is no constitutional bar for a woman to assume responsibilities of a public nature that were discussed in the case.

The Supreme Court decided in the favor of Noor Jehan (famous Pakistani female singer) by giving her a fair share of her right from her father's property in 2016, which was long contested by her brothers. Althought the decision came long after her death (she died in 2000), it paved the way for the acknowledgment of women rights in Pakistan. ${ }^{101}$ The case was decided by a two-member bench, comprised of Justice Ejaz Afzal Khan and Justice Qazi Faez Isa. ${ }^{102}$ In the ruling, they observed, "A sister, to claim her rightful inheritance, was compelled to go to court and suffered long years of agony. However, before she could get what was rightfully hers, she too departed from this world. A quarter of a century has elapsed since the

98 Rafique Bibi v. Sayed Waliuddin, 2004, 1 SCC 287.

99 Mst. Fazal Jan v. Roshan Din and 2 others, PLD. 1992 SC 811.

100 Shahbaz Cheema, "Protection of Legal Status", 619.

101 Nasir Iqbal, "SC gives deceased woman rightful share in inheritance", DAWN, https:// www.dawn.com/news/1243270, last visited 20.4.2020.

102 Ibid. 
death of Haji Sahraney (the deceased father). Such a state of affairs, to say the least, is most unfortunate." 103

Where the infant is illegitimate, custody goes to the woman regardless of the religion of the parents. According to both Islamic and Pakistani law, an illegitimate child belongs only to the mother, and the father has no right to claim custody. In Roshni Desai v Jahanzeb Niazi, ${ }^{104}$ the court awarded the mother the custody of an illegitimate boy. The child's father was a Muslim, while his mother was a Hindu. They were staying in Canada, and they had a son without marriage. The mother demanded custody of the minor when the father brought his son to Pakistan. The High Court of Lahore ruled that such an arrangement was not accepted under Islamic law and the child has been declared illegitimate. The court observed that the father has no association with his illegitimate child in Islamic law and in Pakistani law, and that an illegitimate child belongs to his mother. The court granted the mother custody of the minor and ruled that only maternal relations are eligible to claim custody of an illegitimate infant in case of absence or disqualification of the mother. The father holds no claim to the custody based on the fact that the mother was a non-Muslim.

Moreover, Section 5 of the Dowry and Bridal Gift Restriction Act 1976 states: "All the property given as dowry or bridal gifts and all property given to the bride as a present shall vest absolutely in the bride, and her interest in the property however derived shall hereafter not be restrictive, conditional or limited." Therefore, a gift or benefit was in essence a reward from one person to another according to the Muhammad Ashraf v. Farzana Kousar case in $2016 .{ }^{105}$ In the said case, it was stated that such a gift or benefit will become irrevocable when the materials of a 'gift' have been completed. Thus, the donor would no longer hold any claim of return for such gifts from the donee in case of transfer of possession of such gifted property.

In addition, according to the Punjab Commission on the Status of Women Gender Parity Report, an unprecedented 746 honor killings, 24 stove burnings, 18 cases of divorce marriages, almost 1000 confirmed cases of abduction, 730 cases of gang violence, 31 case of sexual assault and 305 cases of physical abuse were reported in 2017 alone. However, most of the these cases or incidents go unreported and all of these reports go unchallenged. ${ }^{106}$

103 Ibid.

104 Roshni Desai v. Jahanzeb Niazi, 2011 PLD 423.

105 Muhammad Ashraf v. Farzana Kousar, 2016 CLC 1473.

106 Tahmina Rashid, Crimes against women in Pakistan, Policy Forum, 2019. https:// www.policyforum.net/crimes-against-women-in-pakistan/, last visited 7.8.2020. 


\section{CONCLUSION}

Women's rights are human rights that can be secured only if the Pakistani society is free from gender-based violence and addresses women's position by viewing women not only as mothers, daughters, sisters and wives, but also human beings. In the light of the facts presented above about the status of women in Pakistan, improved legislation seems to be an important tool in uplifting and improving the status of women in social, economic and political aspects. For that purpose, it can be seen that the Supreme Court of Pakistan has been continuously supporting and securing women's rights within the constitutional framework by following a progressive interpretation of Sharia law. However, notwithstanding this progressive attitude of the courts of Pakistan towards the status and rights of women, there is still much work left to do in this regard. There is a dire need to find a common core between the rulings/laws of both legal systems in order to find solutions to the existing laws of inequality and subordination of women in Pakistan.

Hence, it is important to organize regular training and awareness programs periodically to make women aware of their rights and empower them to exercise justified demands. In addition, the present laws need to be revised and modified. More specifically, in a dogmatic society in Pakistan, proper law enforcement is critical for providing women with a safe and secure environment to prosper themselves. And there is a need to establish a women's legal assistance centre on a national and district level.

Moreover, while discussing women's status in Pakistan, it becomes evident that Pakistan is tossing between the traditional Sharia law and the modern common law system. This modern legal system has been forced on Pakistan much like every other postcolonial country, but the culture has not fully changed from inside. Therefore, the constant tussle between the two is taking its toll on the female population, resulting in the oppression of women. To sum up, Pakistan needs to address the issue of women's status with acumen, by reducing the existing gulf between theory and practice regarding the empowerment of women. The government of Pakistan must bridge this gap by taking proficient steps to empower the women, who have become a symbol of oppression and disparity not only domestically but also internationally. It should provide the women with opportunities to compete with men on an equal platform, in order to acquire a status parallel to that of the women in other developed countries. 


\section{BIBLIOGRAPHY}

\section{PRIMARY SOURCES:}

Gazette of India, Factories Act, India, 20.8.1934 (Act No. XXV OF 1934).

Hafiz Abdul Waheed v. Asma Jehangir, PLD 2004 SC 219.

Imperial Legislative Council, Code of Civil Procedure, India, 1.1.1908 (Act No. 5 of 1908).

Imperial Legislative Council, Criminal Procedure Code (Cr.P.C), India, 1.4.1898 (Act No. 2 of 1974).

Imperial Legislative Council, Child Marriage Restraint Act, India, 29.9.1929.

Married Women Property Act, England-Wales, 1874 (33 \& 34 Vict. c.93).

Muhammad Ashraf v. Farzana Kousar, 2016 CLC 1473.

Mines Maternity Benefit Act, Pakistan, 26.11.1941 (Act No. XIX of 1941).

Mst. Fazal Jan v. Roshan Din and 2 others, PLD. 1992 SC 811.

Muslim Family Laws Ordinance, 1961, The Official Gazette of Pakistan, 7.10.1958 (Ordinance No. VIII of 1961).

National Assembly Secretariat, Dowry and Bridal Gifts (Restriction) Act, The Gazette of Pakistan, 15.6.1976.

National Assembly, The Constitution of the Islamic Republic of Pakistan, Islamabad 2010.

Offences of Qazaf (Enforcement of Hadd) Ordinance, The Official Gazette of Pakistan, 9.2.1979 (Ordinance No. VIII of 1979).

Pakistan Penal Code (PPC), Pakistan, 6.10.1860 (Act No. XLV of 1860).

Rafique Bibi v. Sayed Waliuddin, 2004, 1 SCC 287.

Roshni Desai v. Jahanzeb Niazi, 2011PLD 423.

Salman Akram Raja vs. Government of Punjab, Constitution Petition No. 38, $2^{\text {nd }}$ October, 2012, 2013 SCMR 203.

Shrin Munir and others v. Government of Punjab and Another, PLD 1990 SC 295. The Dissolution of Muslim Marriage Act, India, 17.3.1939 (Act No. 8 of 1939).

The Guardians and Wards Act, India, 1.7.1890.

The West Pakistan Maternity Benefit Ordinance, The Official Gazette of Pakistan, 22.12.1958 (W.P. Ordinance XXXII OF 1958).

The West Pakistan Family Courts Act, The Official Gazette of Pakistan, 18.7.1964 (Act XXXV of 1964).

Alice Bettencourt, Violence against Women in Pakistan, Litigation Report, Human Rights Advocacy Clinic, 2000. 


\section{SECONDARY SOURCES:}

Ownership of Property in Islamic Law, 2018. https://www.ukessays.com/essays/ anthropology/property-ownership.php, last visited 20.4.2020.

Tahmina Rashid, "Crimes against women in Pakistan", Policy Forum, https://www. policyforum.net/crimes-against-women-in-pakistan/, last visited 7.8.2020.

Athar Ahmad, "The women who sleep with a stranger to save their mariage", $B B C$ News, https://www.bbc.com/news/uk-39480846, last visited 20.04.2020.

Yusuf Al-Hajj Ahmad, The Book of Nikah: Encyclopedia of Islamic Law, Darussalam Publishers, Volume II, 2014.

Shaheen Sardar Ali, Anne Griffiths, From Transnational Relations to Transnational Laws: Northern European Laws at the Crossroads, Routledge, 2016, Chapter 5.

Asghar Ali Engineer, They Too Fought for India's Freedom: The Role of Minorities, Hope India Publications, Gurgaon 2006, 72.

Cheryl Benard, Mapping the Issues: An Introduction To The Range Of Thought In Contemporary Islam, $1^{\text {st }}$ ed., RAND Corporation, Santa Monica 2003.

Tom Brooks-Pollock, "The countries where a majority of Muslims want to live under Sharia law", The Independent, https://www.independent.co.uk/ news/world/countries-where-majority-muslims-want-live-under-sharialaw-a6773666.html, last visited 20.4.2020.

Norman Calder, "Law: Legal Thought and Jurisprudence", John L. Esposito (ed.), The Oxford Encyclopedia of the Islamic World, Oxford University Press, Oxford 2009.

Azam Chaudhary, “The Rule of Law Problems in Pakistan: An Anthropological Perspective of the Daughter's Traditional Share in the Patrimony in the Punjab", Pakistan Journal of History and Culture 30/2009, 101-103.

Imran Sharif Chaudhry, "Gender Inequality in Education and Economic Growth: Case Study of Pakistan”, Pakistan Horizon 60/2007, 81-91.

Shahbaz Cheema, "Protection of Legal Status of Women in Pakistan: An Analysis of the Role of Supreme Court", International Journal of Physical and Social Sciences 4/2014, 615-627.

Karen O'Connor, Gender and Women's Leadership: A Reference Handbook, SAGE Publication, London 2010, 382.

Ahmad S. Dallal, Jocelyn Hendrickson, "Fatwā: Modern usage", John L. Esposito (ed.), The Oxford Encyclopedia of the Islamic World, Oxford University Press, Oxford 2009.

Ronald J. Daniels, “The Legacy of Empire: The Common Law Inheritance and Commitments to Legality in Former British Colonies", The American Journal of Comparative Law 59/2011, 111-178.

John L. Esposito, Natana J. DeLong-Bas, Women in Muslim family law, Syracuse University Press, Syracuse 2001.

John L. Esposito, The Oxford Dictionary of Islam, Oxford University Press, Oxford 2003. 
John L. Esposito, Islamic Law: The Oxford Dictionary of Islam, Oxford University Press, Oxford 2014.

Mohammad Fadel, “Two Women, One Man: Knowledge, Power and Gender in Medieval Sunni Legal Thought", International Journal of Middle East Studies 29/1997, 185-204.

Asaf A. A. Fyzee, Outlines of Muhammadan Law, Oxford Publishers, Oxford 1964.

Abdul Ghafur Muslim, "Islamization of Laws in Pakistan: Problems And Prospects", Islamic Studies 26/1987, 265-276.

Rainer Grote, Constitutionalism in Islamic Countries: Between Upheaval and Continuity. Oxford University Press, Oxford 2012.

Wael B. Hallaq, Sharīa: Theory, Practice, Transformations, Cambridge University Press, Cambridge 2009.

Amna Hassan, "Impact of the European Private Law Codification Outside Europe I: Common Law in the Old Colonial Empire", Dezső Márkus Research Group for Comparative Legal History (DIKE), 3/2020, 170-183.

Nayer Honarvar, "Behind the Veil: Women's Rights in Islamic Societies", Journal of Law and Religion 6/1988, 355-387.

Husssain Haqqani, Pakistan: Between Mosque and Military, Carnegie Endowment, 2010, 18.

Roza Ibrahimova, "Dozens Killed in Violence in Northern Nigeria", Al Jazeera, https://www.dailymotion.com/video/xr5wnq, last visited 20.4.2020.

Masako IIjima, "Islamic Police Tighten Grip on Indonesia's Aceh", Reuters, https://www.reuters.com/article/us-indonesia-aceh-police-idUSTRE60D0 7420100114, last visited 20.4.2020.

Nasir Iqbal, "SC gives deceased woman rightful share in inheritance", $D A W N$, https://www.dawn.com/news/1243270, last visited 20.4.2020.

Khurshid Iqbal, The Right to Development in International Law: The Case of Pakistan, Routledge, 2009.

Ibn Kathir, Tafsir Ibn Kathir, Surah Al Baqarah, Part II.

Charles H. Kennedy, "Islamic Legal Reform and the Status of Women in Pakistan." Journal of Islamic Studies 2/1991, 45-55.

Gilles Kepel, Jihad: The Trail of Political Islam, I.B.Tauris, London 2002.

Nazir Khan, Tesneem Alkiek, Safiah Chowdhury, "Women in Islamic Law: Examining Five Prevalent Myths", https://yaqeeninstitute.org/nazir-khan/women-in-islamic-law-examining-five-prevalentmyths, last visited 20.4.2020..

Ayesha Khan, Nida Kirmani, "Moving Beyond the Binary: Gender-based Activism in Pakistan", Feminist Dissent, 3/2018, 151-191.

Sher Ali Khan, "Global connections: The crackdown on HizbutTahrir intensifies", Herald, DAWN, http://herald.dawn.com/news/1153325, last visited 20.4.2020.

Sir Wilson Roland Knyvet, Anglo-Muhammadan Law, Law Publishing Company, Lahore 1930.

Ira Lapidus, The Cambridge Illustrated History of the Islamic World, Cambridge University Press, Cambridge 1996. 
Roger D. Long, Gurharpal Singh, Yunas Samad, Ian Talbot, State and Nation-Building in Pakistan: Beyond Islam and Security, Routledge, 2015.

Abul A'ala Maududi, Syed Abu-Ala' Maududi's: Introductions to the Qur'an, Amazon 2012.

Ann Elizabeth Mayer, "Law: Modern Legal Reform”, John L. Esposito (ed.), The Oxford Encyclopedia of the Islamic World, Oxford University Press, Oxford 2009, 381-389.

Shampa Mazumdar, Sanjoy Mazumdar, "Rethinking Public and Private Space: Religion and Women in Muslim Society", Journal of Architectural and Planning Research 18/2001, 302-324.

Siam Heng-Heng Michael, Chin Liew Ten, State and Secularism: Perspectives from Asia, World Scientific, Singapore 2010.

Imani Jaafar Mohammad, Charlie Lehmann, “Women's Rights in Islam Regarding Marriage and Divorce", Journal of Law and Practice 4/2011, 1-13.

Annelies Moors, Women Property and Islam: Palestinian Experience 1920-1990, Cambridge University Press, Cambridge 1995.

Papa Murphy, Inheritance Laws in an Islamic Society: Islamic Cultures Are Distinct in Everyway, iUniverse, US 2012.

Sunan An-Nasai, Hadith 20, The Book of Jihad, Chapter 6.

Feisal Naqvi, "Dispute Resolution: A Jury of One", The Counsel, 3/2013.

R. A. Nicholson, A literary history of the Arabs, Cambridge University Press, Cambridge 1969.

Karen Offen, "Women in the Western World", Journal of Women's History 7/1995, $145-151$.

Jan Michiel Otto, Sharia Incorporated: A Comparative Overview of the Legal Systems of Twelve Muslim Countries in Past and Present, Leiden University Press, Leiden 2009.

Jan Michiel Otto, Sharia and National Law in Muslim Countries: Tensions and Opportunities for Dutch and EU Foreign Policy, Amsterdam University Press, Amsterdam 2008.

Mariam S. Pal, Women in Pakistan: Country Briefing Paper, Asian Development Bank, 2000.

Shaun D Pattinson, "The Human Rights Act and the doctrine of precedent", Legal Studies 35/2015, 142-164.

Nadeem F. Paracha, “The first Pakistani?”, DAWN, https://www.dawn.com/news/ 1175127, last visited 20.4.2020.

Intisar A. Rabb, "Law: Civil Law \& Courts", John L. Esposito (ed.), The Oxford Encyclopedia of the Islamic World, Oxford University Press, Oxford 2009.

Shamimur Rahman, "Women's bill sets tough penalties", DAWN, https://web. archive.org/web/20100131230825/http://www.dawn.com/wps/wcm/connect/ dawn-content-library/dawn/news/pakistan/04-zardari-signs-women-protbill-qs-08, last visited 20.4.2020.

Shazia Rafi, "A case for Gandhara", DAWN, https://www.dawn.com/news/1164469, last visited 20.4.2020. 
Staff Report, "President signs two women's rights bills into law", Pakistan Today, https://www.pakistantoday.com.pk/2011/12/23/president-signs-twowomen\%E2\%80\%99s-rights-bills-into-law/, last visited 20.4.2020.

Reuters, "Sherry Rehaman appointed Pakistan's ambassador to US", DAWN, https://www.dawn.com/news/675333/sherry-rehman-appointed-pakistansambassador-to-us, last visited 20.04.2020.

Achim Rohde, State-Society Relations in Ba'thist Iraq: Facing Dictatorship, Routledge, 2014.

Ibn Rushd, Bidayatu'l-Mujtahid (1 ${ }^{\text {st }}$ ed.), Daru'l-Ma'rifah, Beirut 1997.

Alexander David Russel, Muslim Law: An Historical Introduction to the Law of Inheritance, Routledge, 2013.

Rubina Saigol, "Pakistan's Long March", Development and Cooperation 36/2009, 208-210.

Rubina Saigol, "What is the most blatant lie taught through Pakistan textbooks?", Herald, DAWN, https://www.dawn.com/news/1125484, last visited 20.4.2020.

Tad Stahnke, Robert C. Blitt, “The Religion-State Relationship and the Right to Freedom of Religion or Belief: A Comparative Textual Analysis of the Constitutions of Predominantly Muslim Countries", Georgetown Journal of International Law 36/2005, 13-19.

Devin J. Stewart, “Sharia”, Gerhard Böwering, Patricia Crone (ed.), The Princeton Encyclopedia of Islamic Political Thought, Princeton University Press, 2013.

Dr. Abdul Razak Shaikh, "Women's status in Pakistan", DAILY TIMES, https:// dailytimes.com.pk/362564/womens-status-in-pakistan/, last visited 20.4.2020.

M. Mazheruddin Siddiqui, Women in Islam, The Institute of Islamic Culture, 1952, 23-24.

Vatsala Singh, "What does Quran say about Nikah Halala? Will banning it help?", Bloomberg LP/The Quint, https://www.thequint.com/voices/women/so-whatdoes-the-quran-say-about-nikah-halala-triple-talaq-polygamy, last visited 23.4.2020.

Ian Talbot, Pakistan, a Modern History, St. Martin’s Press, New York 1998.

Kashif Mahmood Tariq, "Impact of Anglo-American Jurisprudence on The Pakistan's Legal system”, Pakistan Journal of Islamic Research, 17/2016, 127-140.

Imtiaz Tyab, Pakistani police seeks to recruit more women, Al Jazeera, Doha 2014.

Charris Waddy, Women in Muslim history, Longman ELT, London 1980.

John Wilson, Vikram Sood, Akmal Hussain, Pakistan's economy in historical perspective: The Growth, Power and Poverty, Dorling Kindersley (Pvt) Limited, New Delhi - Washington D.C. 2009.

Afiya Shehrbano Zia, “The reinvention of feminism in Pakistan”, Feminist Review, 91/2009, 29-46.

Farhat J. Ziadeh, “Criminal Law”, John L. Esposito (ed.), The Oxford Encyclopedia of the Islamic World, Oxford University Press, Oxford 2009.

Ira Marvin Lapidus, A History of Islamic Societies, Cambridge University Press, Cambridge 2002. 
ХАСАН Амна

\section{ЖЕНЕ У ПАКИСТАНУ - УПОРЕДНА АНАЛИЗА ПРАВА ЖЕНА НА ОСНОВУ АНГЛОСАКСОНСКЕ И ИСЛАМСКЕ ПРАВНЕ ТРАДИЦИЈЕ}

\section{Сажет̄ак}

Овај рад скреће пажњу на правни положај жена у англосаксонској (соттоп law) и муслиманској правној традицији (шеријатско право) Исламске Републике Пакистан. Он најпре разрађује концепт и историјску позадину шеријатског права. Рад затим детаљно осликава историјску позадину статуса жена у Пакистану на основу два главна параметра, то јест на основу њихових права према шеријатском праву и на основу њихових права у соттоп law систему, тј. по Уставу и законима. Иако шеријатско право начелно поставља жене као једнаке мушкарцима, ипак постоје одређена питања у којима се жене третирају неједнако, попут брака, развода, наслеђивања, стварних права, итд. Рад се закључује свеобухватном анализом права жена у Пакистану под оба правна система кроз анализу судске праксе.

Кључне речи: Жене у Пакистиану. - Сйайус и йрава. - Шеријайско йраво. Common law. - Cüyguja cryчaja.

Рад приспео / Paper received: 29.4.2020. Измењена верзија / Revised version: 2.7.2020. Прихваћен за објављивање / Accepted for publication: 14.8.2020.

* Докторанд на Правном факултету Универзитета у Печуjy, hassan.amna@ajk.pte. hu, maryshah28@gmail.com Овај рад представља део пројекта моје докторске дисертације, под насловом 'Comparative Analysis of Core Issues of Contract Law regarding Anglo-Saxon, Continental, and Sharia Legal Systems with respect to the relevant Statuses of Women'. Представљаће треће поглавље тезе. Такође је прихваћен за конференцију Iustoria 2020, која је одложена због пандемије корона вируса. 